\title{
Pedagogika a paradigmatický obrat v metodologii a teorii ${ }^{1}$
}

\author{
Radim Šíp \\ Masarykova univerzita, Pedagogická fakulta, Katedra sociální pedagogiky
}

Redakci zasláno 11. 8. 2015 / upravená verze obdržena 6. 11. 2015 / k uveřejnění přijato 6. 11. 2015

\begin{abstract}
Abstrakt: Příspěvek popisuje paradigmatický obrat, který pozměňuje raně moderní východiska vědy. Opouští objektivistický realismus a korespondenční teorii pravdy a poznání. $V$ textu autor představuje pragmatistickou teorii poznání (Dewey) a závěry pozdní fenomenologie (Merleau-Ponty, Barbaras, Ricoeur), která znovu objevuje faktické kořeny transcendentální roviny. Oba směry zdůrazňují vliv tělesnosti na proces poznání, což vede k závazkům, jež významně proměňují metafyzická východiska moderní vědy. Změny, které autor popisuje, se dotýkají jak metodologické, tak teoretické roviny. Na rovině metodologie autor poukazuje na to, jak je rozpouštěna př́liš striktní hranice mezi přírodními a sociálními vědami a mezi kvantitativní a kvalitativní metodologií, a dokládá potřebu nahradit tato rozdělení tzv. „kontinuitou disciplinovaného vědeckého výzkumu“. Na teoretické rovině autor popisuje změnu role teorie a význam, jaký v této proměně hraje znovuobjevení somatické dimenze lidského poznání. Všechny tyto změny zásadně proměňují sebereflexi vědy jak na obecné úrovni, tak na úrovni jednotlivých disciplín - tedy i v pedagogice.
\end{abstract}

Klíčová slova: věda, pedagogika, pragmatismus, fenomenologie, pozitivismus, kvalitativní/kvantitativní výzkum, tvrdá/měkká fakta

\section{1 Úvodní poznámky $\mathrm{k}$ terminologii a východiskům předkládaného textu}

Studie původně vznikla jako součást mé odpovědi na recenzi Ivo Jiráska (2015) a pozvolna se proměňovala v samostatnou stat'. Rozdělil jsem nakonec

1 Poznámka redakce: Po poradě s autorem rukopis nebyl anonymizován, nebot' anonymizace by způsobila citelné oslabení argumentační i výkladové linie textu. Anonymita recenzentů vůči autorovi zůstala zachována.

2 První část je snahou o vysvětlení některých nejasností, na něž upozornili recenzenti tohoto textu. Za jejich připomínky jim upřímně děkuji, nebot' mi daly možnost lépe formulovat jistá, ne zcela reflektovaná východiska, jejichž vyjasnění je pro čtenářovo náležité pochopení podstatné. 
svoji odpověd' na Odpověd' a tuto studii. ${ }^{3}$ Ve své podstatě však odpověd' byla především příležitostí zformulovat precizněji ideje, ke kterým jsme já i další členové týmu postupně dospívali během našeho výzkumu tacitních znalostí. Proto je tento text jedním z výstupů zmíněného projektu. ${ }^{4}$ Problematika tacitních znalostí nás vede k přesvědčení, že komplikace, které se objevují, jestliže se snažíme tacitní znalosti detekovat a zkoumat, spočívají v tom, jak je rozuměno znalostem obecně (nikoli tedy pouze těm tacitním). Další výzkum teoretických předpokladů nám umožnil pochopit, že právě v této době dochází $\mathrm{k}$ významné paradigmatické proměně východisek moderní vědy. Zatímco v tradičním - raně moderním - pojetí lze jen těžko a vždy nedokonale tacitní znalost zkoumat, po změně paradigmatických brýlí se nám proměňuje celá „krajina“ porozumění tomu, co je to znalost, i tomu, jak člověk poznává a jaké z toho plynou důsledky pro metodologická tázání i pro proces utváření teorií. Díky tomu se tacitní znalosti stávají čímsi skutečným, co lze smysluplně zkoumat ( $\mathrm{k}$ tomu viz konec čtvrté části).

Jestliže zde píšu o paradigmatickém obratu, činím tak po dlouhých úvahách a s vědomím, že budu muset čtenáře požádat o specifické porozumění. $V$ první verzi tohoto textu jsem věnoval celé čtyři strany popisu změn na úrovni filozofických východisek, na úrovni jednotlivých věd i na úrovni vzniku významných teorií, jež jsou projevem změny na vyšší, obecnější rovině. Vzhledem k maximálnímu rozsahu odborné studie jsem musel tuto část vypustit. Přesto si dovolím zůstat u pojmu paradigmatický obrat, abych naznačil, že se jedná o koherentní a stále silněji se prosazující změnu, jež zasahuje samotné tázání po tom, co je to věda a jaké je její místo v lidském životě. V připravovaném textu Paradigmatický obrat: filozofická analýza současné pedagogiky podrobně popisuji na cca 30 stranách, proč je nutné pochopit paradigma a paradigmatický obrat jiným způsobem, než jak jej chápal Kuhn i jeho nedokonalí epigoni. ${ }^{5}$

Slovo paradigma si sice půjčuji z Kuhnova díla (srov. především 1997), ale významně jeho pojem rozšiřuji, protože paradigmatický obrat v jednotlivých vědeckých disciplínách je pouze jedním z projevů daleko širšího systému změn v celku myšlení a způsobů vypovídání. Kombinuji proto Kuhnův

Redakce Pedagogické orientace uveřejňuje moji odpověd' v tomto čísle (viz s. 733-741).

4 Projekt GAČR (č. 13-200496) Osvojování tacitních znalostí studenty učitelství v průběhu jejich pedagogické praxe.

5 Tato monografie by měla vyjít v jarních měsících roku 2016 v nakladatelstvích Triton a MUNIPress. 
přístup s archeologií vědění M. Foucaulta, s jeho ideou epistém či historického a priori (srov. 2000, 2002). Archeologie vědění ukazuje, jak se změny paralelně projevují i v dalších „tradicích“, z nichž věda či jednotlivé vědecké disciplíny jsou pouze jedněmi z mnoha. Zároveň zde musím upozornit na skutečnost, že paradigma musíme chápat jako weberovský ideální typ (srov. Weber, 2009, především s. 38-63), jako nástroj, který nám umožňuje zaznamenat změny v dlouhém časovém odstupu a v mnoha jednotlivých lidských aktivitách („tradicích“). Takový nástroj je ideálně typickou konstrukcí, která zvýrazňuje a upozorňuje na tendence myšlení, jimž se podřizovala významná většina lidí žijících $\mathrm{v}$ daném období. Neznamená to však, že bychom $\mathrm{v}$ těchto obdobích nenalezli mnoho výjimek, tyto výjimky však byly v podstatném ohledu pouze výjimkami.

Dlouho jsem zvažoval, zda pro tento typ obratu myšlení nemám použít jiný pojem. Např́́klad jsem přemýšlel o Foucaultově pojmu epistéma či historické a priori. Vzhledem k nedostatkům, které shledávám i ve Foucaultově pojetí a především $v$ jeho stylu, a vzhledem ke skutečnosti, že mi nakonec jde především o sebepojetí moderní vědy, dovolil jsem si zůstat u pojmu paradigma i přesto, že podvědomě asociuje Kuhnův záměr i zneužívání, kterému je tento pojem v soudobé odborné literatuře podroben. Musím proto požádat čtenáře, aby neztotožňovali mé pojetí s pojetími, která se projevují např. v diskurzech, v nichž se tvrdí, „že zatímco přírodní vědy jsou monoparadigmatické, sociální vědy jsou většinou polyparadigmatické" atp. Z následujících oddílů bude zřejmé, že takové diskurzy jsou nedostatečné a jdou př́mo proti základním intencím zde předkládaného pojetí paradigmatu jako velké strukturní proměny myšlení. Tato změna se postupně promítá v mnoha tradicích (ve výpovědích vědy, stejně jako ve výpovědích o způsobu oblékání, o způsobu rekreace, o umění) a prosazuje se několik staletí. Pozdně moderní paradigma bylo uvedeno na scénu s objevem významu času v hegelovské filozofii a bylo posíleno objevem evolučního metanarativu, který hluboce proměnil moderní vědu - tedy jeho historie dnes čítá více jak dvě stě let. Dále takový obrat má své kulminační období, kdy nové paradigma střrídá paradigma staré, kdy obě paradigmata žijí a soupeří vedle sebe - právě v takové době dnes žijeme. A nakonec začne slábnout (tak jako se to děje posledních dvě stě let raně modernímu paradigmatu). Je tedy zřejmé, že můj přístup zcela překračuje obzory Kuhnova pojetí, přičemž jej už vůbec nelze ztotožňovat s tím, jak jej užívají Kuhnovi epigoni, kteří píší o paradigmatu jako o něčem, co se dotýká pouze určité profesní skupiny v rámci jedné vědecké disciplíny. 
S paradigmatickým obratem souvisí také má skepse k subjekt-objektovému myšlení, které je centrálním článkem víry raně moderního myšlení. Jestliže $\mathrm{v}$ rámci vědeckých teorií a metateoretických diskuzí o charakteru vědy kritizuji používání slov „subjektivní“ a „objektivní", nečiním tak proto, že bych si nebyl vědom posunů, ke kterým došlo v užívání těchto pojmů během posledních sta let. Např́klad nepopírám, že existuje významná postanalytická kritika mýtu subjektivního, na jejímž konci Davidson rozeznává pouze dva rysy, které z novověkého (raně moderního) pojmu „subjekt“ přetrvávají: 1) že myšlenky jsou soukromé, dějí se „uvnitř“ jednotlivce; a 2) že známe své vlastní myšlenky způsobem, jakým je nemohou znát ostatní (srov. Davidson, 2004, především s. 70-71). ${ }^{6}$ Podobně nepopírám, že pojem „subjektivní“ je ve filozofické literatuře personalismu používán ve významu morální povahy života člověka a morální povahy jeho rozhodnutí (srov. Kohák, 1984, především s. $17-19,82-85,128-130)^{7}$

Přesto se raději slovům „subjektivní" a „objektivní“ a jejich genetickým variacím vyhýbám. Chci tím dát najevo, že jsme stále ještě výrazně pod vlivem objektivistického realismu, který na základě dogmat rané moderny předpokládá, že zde existuje „objektivní", na lidském poznání nezávislý svět a že úkolem vědeckého poznání je objektivizovat původně subjektivní teorie a hypotézy. Tato objektivizace má probíhat tak, že naše teorie konfrontujeme s vnějším, „objektivním“, světem a hledáme, zda s ním naše hypotézy a teorie koresponduji. ${ }^{8}$ Jak si podrobněji ukážeme v daných pasážích z třetí až šesté části tohoto textu, jedná se o představy, které jsou v prŕkrém rozporu se současným stavem poznání toho, jak člověk fakticky poznává.

6 Přesto si zde neodpustím poznámku, že současné kognitivní vědy zpochybňují přinejmenším rys první. Např. teorie rozšířené mysli ukazuje, že naše myšlení nemůže být uzavřeno „uvnitř“ jedince, „uvnitř““ jeho lebky, ale významně překračuje do vnějšího prostoru, protože je utvářeno naším kognitivním aparátem stejně jako naším okolím (srov. Menary, 2010). Podobné myšlenky budu artikulovat v třetí a čtvrté části tohoto textu, $v$ nichž se budeme zabývat pragmatismem a pozdní fenomenologií. Myšlení a naše myšlenky nejsou nikdy zcela soukromé, nikdy zcela „subjektivní“, i když mohou být naprosto intimní.

7 Profesor Kohák připravuje českou verzi této obdivuhodné knihy (předpokládané období vydání je jaro 2016), kde vztah mezi slovem „subjektivní“ a morálním smyslem lidského života bude ještě zřejmější, nebot' je velmi složité smysluplně překládat anglické pojmy personal a person, a tak se v jistých kontextech překládají jako subjektivní a subjekt.

$8 \quad$ Systematickou charakteristiku objektivistického realismu a důvody pro jeho odmítnutí, které plynou z výsledků současných výzkumů kognitivních věd (a které jsou v souladu s mnohými filozofickými předpoklady pragmatismu a fenomenologie), může čtenář najít v Lakoffově knize Ženy, oheň a nebezpečné věci (2006). Zde je představen projekt, který se snaží „zachránit realismus tím, že jej zbaví objektivismu“ (srov. především s. 11-16 a 161-359). Přesně na těchto myšlenkách je postavena idea transformace vědy, kterou budu v této studii představovat. 
A konečně zde musím vyjasnit své porozumění fenomenologii jako velkému a velice diferenciovanému proudu soudobého myšlení. V tomto textu se budu obracet $\mathrm{k}$ té části fenomenologického myšlení, která využívá pozdních myšlenek E. Husserla (srov. především 1996) a některých analýz M. Heideggera, ale významně je překračuje směrem, jenž věnuje velkou pozornost tomu, jak je (nejen) lidské myšlení utvářeno svojí tělesností a jak je to právě tělesnost, která veškeré organismy umist'uje do smysluplného řádu světa živých bytostí. Obracím se zde k linii myšlení, jež se od zmíněných zakladatelů táhne dál k Merleau-Pontymu (srov. 2004), Henrymu (srov. 2010), Levinasovi (srov. 1997) a Barbarasovi (srov. 2005) a která nachází svůj český odraz v monografii editované P. Urbanem Fenomenologie tělesnosti (2011). ${ }^{9}$

Znovuobjevení tělesnosti ve fenomenologii nám umožňuje nacházet faktické kořeny transcendentální roviny, které, jak ukážeme v části čtvrté a páté, vedou k největším změnám $v$ metodologických východiscích pozdně moderní vědy a k docenění teorií, jež si všímají neopomenutelné důležitosti somatického podkladu pro utváření kognitivních funkcí člověka (organismu) - k tomu viz šestá část. Je zřejmé, že má inspirace fenomenologií vychází z této (především francouzské) fenomenologické tradice, což mě naopak staví do opozice k těm českým fenomenologům, kteří se příliš přimykají k původnímu Husserlovu projektu, jenž je nejlépe charakterizován Logickými zkoumáními či Formální a transcendentální logikou (2007), tedy do opozice k fenomenologům, pro které je vědomí a transcendentální rovina nepřekročitelnou hranicí. Zdá se, že přítel Ivo Jirásek je zastáncem právě tohoto tradičnějšího proudu.

\section{Změna schématu myšlení: smíření pozitivismu a fenomenologie}

Jednu pasáž ze zmiňované recenze Ivo Jiráska stojí za to ocitovat i zde, protože bude udávat tón celé této studii:

Málo je zřejmé, proč by mělo být souvislé pole reality zkoumáno metodami, mezi nimiž je rovněž plynulý přechod: je-li na jedné straně opora o pozitivismus (kvantitativní přístupy) a na druhé o fenomenologii a hermeneutiku (kvalitativní), jen obtížně můžeme hledat ,něco mezi tím', co by tyto protikladné př́stupy ke světu propojily. (Jirásek, 2015, s. 490)

V této souvislosti bych rád připomněl originální a intelektuálně hluboký text Alice Koubové Myslet ze štastného těla, který není zahrnut do zmíněné monografie, ale vyšel jako součást monotematického čísla Filosofického časopisu (2011). 
Ivo Jirásek tím nesouhlasně reagoval na moji tezi, že v blízké budoucnosti se již nebude striktně odlišovat využití metodologických přístupů podle toho, zda se nacházíme v „přírodních“ či v „sociálních“ vědách. Domnívá se naopak, tak jako mnozí tradiční teoretici vědy, že mezi kvantitativní a kvalitativní metodologií vězí nepřekročitelná propast, nebot' každý z obou př́istupů vychází z jiného filozofického východiska.

Obě východiska však mají společný kadlub myšlení. Vznikly v 19. století jako různé odpovědi na stejné problémy objektivistického realismu rané moderny. Toto společné schéma myšlení prochází již šedesát let proměnami, jež se promítají i do původních východisek samotných filozofických směrů. ${ }^{10}$ Hlavním cílem této studie je ukázat cestu $\mathrm{z}$ raně moderního myšlení v pedagogice k myšlení pozdně modernímu - nejen ve vědě obecně, ale především i v pedagogice. ${ }^{11}$

Ve třetí a čtvrté části se vrátím k některým názorům Ivo Jiráska, které se týkají pragmatismu a fenomenologie, abych dokumentoval, že jsou to právě tyto dva filozofické směry, jež nám umožňují redefinovat př́iliš striktní rozlišení na př́rodní a sociální vědy a redefinovat odlišnosti a podobnosti kvantitativních a kvalitativních metodologií. Oba směry přicházejí s převratnou myšlenkou: člověk a jeho okolí tvoří homeostatickou jednotu. Člověk je jako jedinec i jako druh utvářen svým prostředím a naopak prostředí je utvářeno člověkem. Nikoli ovšem v onom tradičním slova smyslu, že jedno mechanicky působí na druhé a naopak, ale ve smyslu skutečné „organické", homeostatické jednoty - prostředí svým vlivem prostupuje do organismu a proměňuje jeho životní strukturu a změna struktury organismu zpětně působí na prostředí. $\mathrm{Z}$ toho plynou vážné důsledky pro epistemologii. Mění se s tím kompletně představa toho, jaké informace a jakým způsobem můžeme prostřednictvím našeho výzkumu získávat. Oba filozofické směry tak mohly zcela novým způsobem kritizovat tradiční neopozitivistické (objektivistické) pojetí poznání a poskytnout nástroje $\mathrm{k}$ transformaci pozitivismu, objektivismu.

10 Jedním z výrazných rysů paradigmatického obratu je skutečnost, že některé filozofické směry, jež se zdály být nesmiřitelné, je možné po jejich transformaci propojit do stejného epistemologického pozadí.

11 Pozdní modernu stavím proti rané moderně jako další fázi moderního myšlení, která překonává jednostrannosti fáze první. Vědomě se vyhýbám pojmu „postmoderna“, protože postmoderní myšlení je dovršením jednostranností rané moderny, které se promítají do stejně jednostranných idejí v pedagogice, jež ve svých důsledcích otevírají dveře komercionalizaci a klientelizaci pedagogiky. 
Ovšem ani tyto směry samotné - především fenomenologie - nezůstaly ve svém původním rozvrhu. Původní program fenomenologie jako transcendentální disciplíny se sám proměnil. Díky tomu můžeme transcendentální rovinu ${ }^{12}$ pochopit jako empirickou, specificky se utvárející rovinu fylogenetického a posteriori, které se z pohledu jedince či z pohledu několika generací jeví jako ontogenetické a priori - jako transcendentální rovina. Jestliže přistoupíme na ideje, jež jsou ve třetí a čtvrté části obhajovány, pak z nich plynou závažné závazky pro vědu obecně a pro pedagogiku zvlášt'. Na konci obou zmíněných částí budou tyto závazky artikulovány.

Se závazky úzce souvisí téma idealizace. Idealizací míním specifické způsoby redukcí, kterými musí projít fenomény, jež hodláme vědecky zkoumat kvantitativními metodami. Pedagogika je vědou, jejíž fenomény jsou mnohem více než fenomény jiných disciplín prostoupeny zpětnovazebnou reflexí, která se promítá do transcendentální struktury vnímání a poznání a která zároveň utváří významnou a neoddělitelnou vrstvu hodnot. Jestliže tyto hodnoty redukujeme (idealizujeme) hned na počátku výzkumu tím, že je podřídíme procesům použití kvantitativní metodologie, pak právě tuto vrstvu ztrácíme. Tím ale již na počátku výzkumu vytváŕíme zcela odlišnou realitu od té, kterou jsme chtěli původně zkoumat. Tento projev nesprávného uplatnění kvantitativní metodologie na př́slušném místě nazývám mizení předmětu pedagogiky a ukazuji, že toto mizení je zapříčiněno raně moderní ideologií vědy.

Transformace filozofických východisek mají své významné dopady i na utváření teorií a na jejich funkci. V předposlední části textu budu ukazovat na příkladu některých pedagogických teorií a jejich konceptů, že mnozí výzkumníci nedocenili téma homeostatické podstaty vztahu mezi člověkem a prostředím. To se projevuje několika způsoby - např́íklad tak, že jsou vedle sebe kladeny koncepty natolik odlišné, vycházející z odlišných paradigmat myšlení, že jakákoliv teorie, která by vznikla kombinací těchto konceptů, by byla v praxi nepoužitelná. Nakonec na konkrétním př́́kladu rozpačitého přijetí Hejného metody budu dokumentovat jiný projev nedocenění paradigmatického obratu, budu ukazovat, že jestliže nedoceníme somatickou dimenzi kognitivních aktů a jestliže nebudeme klást důraz na vztahovou podstatu skutečnosti - což jsou zásadní východiska pozdně moderního paradigmatu - pak

12 Zjednodušeně si můžeme transcendentální rovinu definovat jako apriorní strukturu vnímání a zakoušení, která formuje naše prožitky a poznatky do smysluplného celku. Bez takovéto předem dané (proto transcendentální, nikoli empirické) struktury bychom nebyli schopni uspořádat ani náš život, ani naše poznatky. Myšlenka transcendentální struktury byla již definována Kantem a Husserl v tomto projektu původně pokračoval. Díky důslednosti svých analýz však projekt významně překročil. (Více viz níže.) 
nemůžeme nikdy náležitě docenit systém předpokladů, na němž Hejného metoda spočívá.

\section{Pragmatismus není „starý známý“}

Když jsem ve své stati (in Gulová \& Šíp, 2013, s. 12-37) představoval paradigmatický obrat a nové paradigma vědy a vědeckého výzkumu, skutečně jsem svůj výklad opřel o pragmatismus. Nejedná se však o „starý známý pragmatismus “13, jak se Ivo Jirásek domnívá (srov. 2015, s. 489), protože pragmatismu se v česko-slovenském prostoru do hloubky věnuje jen málokdo (jako čestné výjimky mohu jmenovat Emila Višňovského, Františka Mihinu či Romana Madziu' ${ }^{14}$ ).

Těsně před svou smrtí William James, ve snaze osvobodit pojem zkušenosti z jeho novověkých závazků a omezení, začal razit pojem double-barreled experience („podvojná zkušenost“). ${ }^{15}$ Taková zkušenost v sobě zahrnuje cíl i aktivitu, jež daného cíle dosahuje. $S$ touto myšlenkou se v pragmatistické filozofii jasněji artikuluje intuice, která v něm byla od začátku. Intuice, že do utváření významů a poznatků vstupují jak „subjekty“, tak „objekty“ poznání, přesněji že zkušenost není „subjektivní“, ale zároveň nemá charakter tzv. „objektivního poznatku“. ${ }^{16}$ Zkušenost je kontinuitou mezi jednajícím organismem (člověkem) a prostředím, ve kterém organismus jedná. Zkušenost

13 Pragmatismus není v Čechách „starý známý“. Když si však otevřeme většinu publikací z české provenience, jež o pragmatismu nějak referují, pak se dostaneme ke starým známým zař́ikávadlům, které se zde tradují již od dob sporu dvou pedagogů, Václava Př́íhody a Otokara Chlupa: pragmatismus má blízko k pozitivismu, je zplanělou filozofií, protože mu nejde o pravdu a ústí do behaviorismu, $v$ jiných verzích do subjektivismu, přičemž nadřazuje individuum nad společnost a nad její hodnoty tím, že podporuje užitečnost poznání a výkonnost. Jednalo se především o mínění brněnského (Chlupova) okruhu. Chlupovy názory však nebyly zcela mylné. Př́ihodovské pojetí, které bylo spíše pozitivistické a behavioristické, jistě nebylo „pragmatistické“ (srov. Kotáa, 2015). Ale právě tato záměna z neznalosti zformovala základní česko-slovenský narativ o tom, „,co to pragmatismus je“. To je také důvod, proč inspirován E. Višňovským a R. Madziou užívám neologismy pragmatista a pragmatistický, abych skutečný pragmatismus odlišil od slov pragmatik a pragmatický, které jsou produktem tohoto narativu.

14 Madziovu knihu George Herbert Mead: Tělo, mysl, svět (2014) vřele doporučuji všem, kteří se chtějí dotknout skutečného pragmatismu a zároveň poznat jeho nejnovější spolupráci $\mathrm{s}$ fenomenologií a kognitivními vědami.

15 Přesný termín, který by vyjadřoval onu „dvojitou hlavňovitost“ či „vlastnost dvojité hlavně“ (double-barreled), v češtině patrně chybí. Proto volím překlad „podvojná“ (zkušenost) a budu vděčný každému, kdo mi nabídne lepší překlad.

16 Uvozovky u slov „subjektivní“ a „objektivní“ naznačují myšlenku, kterou jsem již artikuloval v první části tohoto textu. 
je funkcí života a překračuje hranice kůže člověka, není „,subjektivní“, je utvářena reálným děním $v$ prostředí. Tato kontinuita zakoušení a zakoušeného tvoří celek, který teprve $\mathrm{v}$ reflexi rozčleňujeme, a tak vzniká pól subjektu a pól objektů. „Subjekt“ a „objekt" je něčím, čeho dosahujeme až v reflexi, je tedy z hlediska kognitivního aktu něčím druhotným (i když stále významným). James to vyjadřuje neologismy „sight-seeing“, „heard-hearing“ (viděné-vidění, slyšené-slyšení), které teprve v sekundární zkušenosti (zjednodušeně řečeno $v$ reflektované zkušenosti) od sebe odděluje to, co bylo viděno/ slyšeno, od aktivity „subjektu“ - od toho, co „subjekt“ vidí/slyší.

Podobným směrem míři i fenomenologická tradice. Když Patočka sleduje kořeny intencionality až k Aristotelovu spisu $O$ duši (Patočka, 2003, s. 26-28), mluví o Aristotelově „podobě“, v níž se propojují afektivní a kognitivní akty se svými objekty, na které jsou tyto akty zaměřeny. Základní formou všech těchto podob je aisthesis-aistheton, tedy zakoušení-zakoušené. Kdo dobře studoval pozdější Husserlovu snahu o (re)konstituci druhého a světa v zakoušejícím Já, tzn. kdo studoval proměnu kategorie intencionality, jistě mu neunikla hluboká souvislost mezi pojetím intencionality a asubjektivním charakterem zkušenosti v pragmatismu. ${ }^{17}$ Pragmatismus (Mead, James, Dewey, Johnson a další), stejně jako fenomenologie (Husserl, Heidegger, Merleau-Ponty, Levinas a další) se pokouší ukázat, že naše pojetí subjektivity a objektivity bylo sice zpočátku pro vědu rané moderny relativně úspěšné řešení, ale řešení v konečných důsledcích dlouhodobě neudržitelné. Ovšem právě toto řešení stále vězí v samotném centru sebepojetí současné vědy.

Jestliže ale vezmeme důsledky pragmatistického pojetí asubjektivní zkušenosti (a fenomenologického pojetí intencionality) vážně, pak musíme čelit závazným důsledkům, které mají vliv na naši teorii poznání. Pravdivost poznatku nemůže být definována prostřednictvím ideje objektivity. Dewey byl jedním z těch, kdo se $\mathrm{v}$ době moderny pokoušel promýšlet poznání $\mathrm{z}$ neobjektivistických pozic. Protože zde není prostor pro detailní analýzu jeho teorie poznání18 ${ }^{18}$, budu se zde ve zkratce věnovat pouze třem tématům: roli

17 K tomu je ovšem nutné znát, o čem pragmatismus skutečně je.

18 K hlubšímu pochopení Deweyho teorie poznání viz Šíp (2014), popř. viz studie Emila Višňovského (2009, s. 92-115). Nebo je možné čerpat př́mo z Deweyho textů: The Logic of the Judgments of Practice (mw.8: 14-82); How We Think (revised edititon) (lw.8: 105-352); Logic: The Theory of Inquiry (lw.12); Knowing and the Known (lw.16: 1-293). (Co se týče způsobu odkazu na Deweyho dílo, jedná se o standardizovaný odkaz na jeho sebrané spisy [Collected Works] - „mw“ znamená dílo středního období; „lw“ dílo pozdního období, číslo po tečce svazek, v němž se text nachází, a číselné rozmezí po dvojtečce strany od-do.) 
jednání v procesu poznání, roli praktického soudu v procesu poznání a teorii situovanosti.

Objektivismus ${ }^{19}$ je založen na vizuální metaforice uchopování pravdivého poznatku, kterou raná moderna převzala $\mathrm{z}$ anticko-scholastického paradigmatu myšlení. Právě tato výpůjčka činí ranou modernu rozporuplnou a vede vědu k představě, že podstatou poznání je korespondence našeho poznatku o světě (naší reprezentace světa) se světem samotným. Tato vizuální metaforika nám říká: Svět (jeho stavy na konkrétním místě a v konkrétním čase) bezprostředně uchopujeme prostřednictvím naší mentální či pojmové reprezentace a jediné, co musíme zajistit, je, aby tato reprezentace byla náležitá, aby „korespondovala“ se světem (s jeho příslušným stavem). ${ }^{20}$ Taková východiska předem zcela vylučují jednání z procesu poznání, což je mimochodem v hlubokém rozporu s baconovskou tradicí moderní vědy. Dewey se snaží tato předporozumění rané moderny (a potažmo anticko-scholastického období) kompletně převrátit a pozměnit.

V jeho metafyzice je jednání přiděleno místo, kterého bylo zbaveno již v antické teorii poznání. Jednání je na počátku celého procesu (vidíme, cítíme, dotýkáme se...), poté je jím poznání modifikováno (přistupujeme, ovládáme, manipulujeme, opakujeme pohyby, opakujeme techniky, proměňujeme přístupy, experimentujeme) a to vše nám umožňuje ukončit celou sekvenci kontinua jednání, percepce a poznání (tedy kontinuity zkušenosti) tím, že si vytyčíme cíl ve výhledu. ${ }^{21}$ Jestliže máme cíl ve výhledu, můžeme formulovat

19 Kdetailnímu popisu opět viz výše zmíněné pasáže z Lakoffovy knihy (2006,s. 11-16,161-359).

20 Rorty ve své analýze raně moderní filozofie a vědy tuto činnost ironicky pojmenoval „leštěním zrcadla" - musíme zajistit, aby naše mentální zrcadlo bylo čisté a odráželo objekty světa náležitě. Rortyho kniha (2012) je další velmi zdařilou analýzou celé raně moderní tradice i s jejich rozporuplnými důsledky.

21 Dewey k popisu této fáze poznání zavádí neologismus end-in-view (Višňovský jej překládá „výhledový cíl“- srov. 2009, s. 10). Jen v nějakém výhledu, v nějakém zaměření našeho života, jsme schopni říct toto a toto je dobré, je potřeba toho dosáhnout. To je hlavní podstata instrumentality poznatku v moderní vědě. Poznání neznamená kopírování světa, ale artikulaci světa takovým způsobem, abychom věděli, jak náležitě jednat. Být zdravý je dobré, a proto musím jednat takovým způsobem, abych si zdraví zachoval nebo abych zdraví opět nabyl. Umět idealizovat realitu prostřednictvím matematických vztahů je dobré a musíme dítě učit takovým obsahům, takovým způsobem a v takovém věku, aby se co možná nejsnáze této idealizaci naučilo. Přesto zde leží samotný zdroj nepochopení pragmatismu. Tento typ instrumentality, bez kterého by nemohla existovat moderní věda, si kritici pragmatismu mylně vyložili jako kognitivní utilitarismus, kterému nejde o pravdu, a zesměšňovali jej jako v podstatě nefilozofickou, účelovou honbu za ziskem (srov. např. Ochrana, 2009, s. 143). 
praktické soudy (judgments of practice) - propozice svého druhu, prostřednictvím kterých jsme schopni navrhovat jednání vedoucí ke stanovenému cíli. Pokud zapojíme alternativní jednání, dostáváme se $\mathrm{k}$ jeho důsledkủm, jež můžeme zpětně zhodnotit jako bud' očekávané, nebo neočekávané, jako uspokojující, nebo neuspokojující. Dosáhli jsme cíle ve výhledu, nebo nikoli? Mentální obrazy a propozice jsou v tomto pojetí chápány nikoli jako zrcadlení reality, ale jako „výrobky“ naší inteligence, která tvaruje zkušenostní materiál tak, aby byl zformován do podoby praktických soudů. Soudy jsou návrhy, jak jednat způsobem, abychom byli schopni řešit situaci, v níž se nacházíme.

Pojem situace však není v Deweyho metafyzice používán intuitivně, ale hraje klíčovou roli, je to jeho terminus technicus: Situace vyjadřuje základní vlastnost - naprostou provázanost jednajícího se svým okolím. Dewey tím má na mysli fakt, že člověk (stejně jako jakýkoli jiný organismus) tvoří se svým okolím celek, který nemůžeme jednoduše rozčlenit na subjekt a objekt poznání tak, jak to podvědomě lidé činí od 17 . století. ${ }^{22}$ Proto také nemůžeme chápat pravdivé poznání jako kopírování reality (objektu) v mentálních a pojmových reprezentacích subjektu. Kdybychom vyčlenili z jednolité situace aspekt „já“ a aspekt „prostředí", vytvořili bychom zcela oddělené entity (subjekt x objekt). Tak bychom se dostali do koloběhu předpokladů, které nás nakonec přivedou bud' ke korespondenční teorii pravdy a poznání, jež je ale vnitřně rozporuplná, anebo k epistemologickému skepticismu - nejsme schopni poznat nic, vše jsou pouze naše zvyky a subjektivní přesvědčení.

V Deweyho experimentální metafyzice však mohou být „pravdivé“ či „nepravdivé“ pouze výsledky našeho jednání. „Pravda“ a „nepravda“ jsou funkcionálním vyjádřením složitě strukturovaného stavu, v němž naše jednání bud' odpovídá dané situaci, uspokojivě ji řeší (pravda), nebo jí neodpovídá, neřeší ji, popř̀ vytváří ještě více problémů a neporozumění (nepravda). Propozice či mentální stavy tu nejsou od toho, aby byly „pravdivé“ či „nepravdivé“, ale od toho, aby sloužily k artikulaci situace - aby ji učinily určitou, přehlednější. Tím, že se poznávající soustředí na jisté aspekty situace, je posléze schopen určit alternativy budoucího jednání. Tak z neurčité (undetermined situation) vzniká situace určitá či zpřesněná (determined). Bez zpřesnění bychom nedokázali určit, jak jednat, jak danou situaci řešit.

22 Tím se opět vracíme k podvojnosti zkušenosti, $\mathrm{k}$ fenomenologické intencionalitě, $\mathrm{k}$ tomu, co je velmi blízké výsledku Heideggerovy analýzy pobytu, a k tomu, co ve vztahu k Deweyho teorii poznání nazývám asubjektivní relací mezi organismem a jeho prostředím. 
Zpřesňování situace je jejím schematizováním pomocí našich praktických soudů. Díky procesu schematizování je poznávající schopen navrhnout jednání, o kterém se domnívá, že je více přiměřené než to, jehož byl schopen před zpřesněním situace. Propozice jsou samozřejmě nejúčinnějšími lidskými prostředky, jak situaci zpřehlednit, a tak určit další způsob jednání. Proto jsou praktickými soudy. Zpřesněná situace je ale konstrukcí, zjednodušením, schematizací nějakého výseku světa. Tím, že jsme některé jeho aspekty zvýraznili, abychom byli schopni jednat, jiné aspekty nám díky takovému zpřesnění ustoupily do pozadí. Staly se implicitní, tacitní. Poznání chtě nechtě je vždy pulzováním mezi malou částí explicitních poznatků a mnohem větší částí poznatků implicitních, tacitních.

Ze všech právě zmíněných důvodů nemůžeme poznání chápat jako hledání korespondence mezi našimi reprezentacemi a pravými strukturami světa. Ovšem právě na této ideji „obrázkování“ je založený objektivismus se všemi svými rozpory. S objektivismem a s jeho pojetím poznání jako korespondence je vnitřně spojena také idea oddělení popisu (roviny faktů) od předpisu (od roviny norem a hodnot). $V$ raně moderním paradigmatu má věda poskytovat pouze popis - poskytovat pravý obrázek „toho, jak se to se světem má“ - ale nikoli předpis - hodnoty, kvalitativní určení, která jsou na hodnoty napojená, a dokonce nemá poskytovat ani hodnotové motivace samotného výzkumu. Přesně na takových ideách je vystavěna představa pedagogiky jako vědy o výchově (Erziehungwissenschaft), jak ji definuje pozitivisticky laděná německá škola, aby konečně zajistila pedagogice status vědy. Takto formulovanou definici pedagogiky nacházíme ještě v Brezinkově „trojdomém“ pojetí pedagogiky (srov. 2001, především s. 38-83). Brezinka si však již uvědomuje, že se bez hodnot v pedagogice neobejdeme, a proto je do svého systému zavádí v podobě světonázorového určení filozofie výchovy. Pokud však nevycházíme z pozitivistických východisek, nemusíme ani konstruovat takto krkolomný systém. $V$ reálném světě jsou fakta a hodnoty prrítomny a navzájem se určují. Poznáváme je ruku v ruce. ${ }^{23}$ Jinými slovy pozitivistická škola formující vědu o výchově dělá pedagogice medvědí službu, protože ji svazuje se vší rozporuplností rané moderny.

Pragmatistické (a pozdně fenomenologické) analýzy podstaty vědy nás v pedagogice zavazují několika způsoby. Prvním závazkem je to, že nesmíme

23 Více k této problematice viz př́slušnou část připravované monografie Paradigmatický obrat: filozofická analýza současné pedagogiky. 
rozumět poznání jako korespondenci. Pedagogika studuje mnohem komplexnější systémy než napřr. novověce idealizovaná psychologie, v níž si vědci mohou vystačit s kvantitativní metodologií a netransformovanými neopozitivistickými východisky. ${ }^{24}$ Proto jakmile se v pedagogice uchýlíme k představě poznání jako korespondence, pak se opět vracíme k raně moderním dichotomiím popis (deskripce reality) vs. předpis (normy či hodnoty). Tím se pedagogika jako věda začne vytrácet, protože její podstatou je sounáležitost reálného světa s dynamicky se ustavujícími normami. Nejenže bez norem nepřežije žádný jednotlivec ani žádná společnost, nejenže i ten "nejčistší vědecký výzkum je motivován a veden systémem určitých norem a hodnot, ale také - a především - se bez nich neobejde žádný reálný pedagogický výkon. Jakmile z popisu vyloučíme předpis, začne se jakýkoli pedagogický výkon jevit jako uplatnění voluntaristické ideologie některé ze zájmových skupin. Přesně tento typ skepticismu se projevuje v postmoderní kritice pedagogiky, která jako svůj nezamýšlený důsledek otevírá dveře komercionalizaci a klientelizaci školských systémů.

Druhým závazkem je závazek propojení teorie a praxe. ${ }^{25} \mathrm{Z}$ Deweyho teorie poznání vyplývá, že výsledky výzkumu se stávají pravdivé teprve tehdy, jestliže jejich závěry (ve své podstatě návrhy alternativního jednání) jsou aplikovány do praxe a v praxi vedou $\mathrm{k}$ tomu, $\mathrm{k}$ čemu podle praktických soudů (judgments of practice) měly vést. Tím, že se pedagogika ve svém výzkumu a teorii povětšinou spoléhá na korespondenční teorii pravdy a poznání, systémově zvětšuje propast mezi svou teorií a praxí, nebot' se pravdivým poznatkem často stává takový poznatek, který je konformní s „náležitým“ výzkumným (metodologickým) postupem. Stává se to především (nikoli ale výlučně) v kvantitativních výzkumech, jejichž formalizace je díky procesu idealiza-

24 Viz např behaviorismus na jedné či kognitivimus inspirovaný kognitivními vědami první generace na straně druhé.

25 V kontextu otázek kolem teorie a praxe v pedagogice byla u nás tato problematika zpracována Višňovským, Kaščákem a Pupalou (2012). V něm se autoři v podstatě vracejí k dvěma praxím aristotelské metafyziky (srov. 308-312), které chtějí propojit v roli pedagogavýzkumníka a pedagoga-praktika (učitele) (srov. s. 331-332). Problém ovšem podle mého nenastal v novověku, ale právě již u starých Řeků, kteří vycházejíce ze své ideologie poznání jako kontemplace (srov. lw.1: 75-81), roztrhli kontinuum života organismu, a tím oddělili „skutečné poznání“ (epistémé) od „praktického poznání“ (fronésis). Vytvořili tak dichotomii dvou odlišných „praxí": kontemplativní teorie vs. poznávající praxe. Jinými slovy z kontinuální funkce života vytvořili „systém bud'/anebo“. Měli-li bychom pedagogiku „léčit“ nějakým návratem, pak bychom se museli vrátit až hluboko před Aristotela a Platóna. Možná by stačilo, kdybychom místo návratů do dávné historie vzali skutečně vážně dílo Deweyho či Piageta. 
ce fenoménu podstatně jednodušší. ${ }^{26}$ Poznatek je pravdivý tehdy, jestliže je předem zformalizovaným způsobem (který v mnohém připomíná formalizace středověké vrcholné scholastiky) potvrzena jeho validita a reliabilita. 0 uplatnění takových výsledků v praxi se často ani neuvažuje, protože pravdivost je definována pomocí ideje „obrázkování“ a je nakonec „zajištována“ již předem pouze na teoretické rovině. Je předem „zajištována“ požadovanou korespondencí - ovšem nikoli korespondencí se světem, ale s „náležitým“ metodologickým postupem.

Tato záměna korespondence mezi naší teorií a světem za korespondenci mezi teorií a předem daným metodologickým postupem je systémovým důsledkem rozporuplnosti korespondenční teorie pravdy a poznání. Nikdy totiž nejsme schopni poměřit náš poznatek / naši teorii s realitou, protože nejsme z principu schopni nahlédnout realitu takovou, jaká je, nezávisle na našich poznatcích a teoriích. Vždy poměřujeme pouze jeden náš poznatek se systémem dalších poznatků, které považujeme za pravdivé. A protože nám k těmto poznatkům dopomohly určité metodologické postupy a protože $\mathrm{v}$ raně moderním paradigmatu vědy musíme chápat poznání jako korespondenci, spokojujeme se alespoň s korespondencí mezi tím, jak byl poznatek reálně získán, a tím, jak byl v historii vědeckého výzkumu formalizován „příslušný" metodologický postup. To není nic proti kvantitativní či kvalitativní metodologii, ale proti jejich uplatnění v reálném výzkumu. Kdybychom totiž v pedagogice o pravdivosti poznatků či teorií důsledně rozhodovali až po jejich uplatnění či neuplatnění v praxi na základě dosažené či nedosažené praktické zamýšlené změny k lepšímu, pak by se v mnoha případech „pravdivých“ poznatků a teorií ukázalo, že jsou „pravdivé“ pouze na úrovni „teorie“.

\section{Fenomenologie není „transcendentální“}

Pragmatismus u nás - na rozdíl od Německa, Polska či Mad’arska - není náležitě studován, a tedy není „starý známý“. Stejně tak ale transcendentální fenomenologie není ve svých konečných důsledcích „transcendentální", jak Ivo Jirásek tvrdí: „Husserlova fenomenologie je povýtce transcendentální, nikoli empirická" (2015, s. 490). Kdyby znal detailně polemiku Renauda Barbarase (jednoho z významných soudobých znalců Husserlova a Merleau-Pontyho díla) s Husserlovým transcendentálním projektem (viz jeho Touha a odstup - 2005), pak by Ivo Jirásek - jak znám jeho poctivou duši - jistě nezaujal tak

26 K idealizaci ve vědeckém výzkumu viz další části textu. 
jednoznačný soud. Nicméně at' už by se přítel Jirásek přiklonil na jakoukoli stranu, podstatné zde je, že téma transcendentality je z hlediska metodologie pedagogického výzkumu skutečně stěžejní!

Podobné závěry těm, které v polemice s Husserlem předkládá Barbaras, najdeme již v Gadamerově textu ze šedesátých let 20. století: „Nekonečnost minulosti, ale především otevřenost dějinné budoucnosti se s žádnou takovou ideou dějinného univerza neslučuje. Husserl tento závěr výslovně vyvodil, aniž se zalekl ,strašáka' relativismu" (Gadamer, 2010, s. 221). S tímto pohybem dějinného univerza, který jde zcela proti logice raně moderního pojetí vědy a jejího ideálu poznávání světa, se do pohybu dostává i Husserlova transcendentální rovina. Husserl v dodatcích ke Krizi evropských věd píše o „Všech vágních možnostech uskutečnitelného prožívání a konání“, které utvářejí horizont vší konečnosti prožívání, konání a také poznání jednotlivců i společenství (srov. Husserl, 1996, s. 538). Právě zde se dostává na hranici svého transcendentálního projektu a (možná nevědomě) ji překračuje. Zmíněné „možnosti uskutečnitelného prožívání a konání“ jsou neuchopitelné, neobjektivizovatelné mimo jiné proto, že se podílejí na neustálé rekonstituci transcendentální roviny. Barbaras ve své kritice pokračuje dále a všímá si zamlčené fakticity (empiričnosti) transcendentální roviny:

Místo, aby [Husserl] uznal, že původní charakter touhy ${ }^{27}$ vede ke kladení konstitutivního včlenění transcendentálna do faktičnosti, interpretuje samu faktičnost jako předznamenání konstituce předmětu poznání ze strany vědomí, majícího bezvýhradnou vládu nad sebou samým. [...] Místo aby rozpoznal určitou faktičnost transcendentálna, transcendentalizuje faktičnost samu. (Barbaras, 2005, s. 152)

Tato „transcendentalizace faktičnosti“ je novověkou (raně moderní) stopou v Husserlově projektu. Pokud uznáme původní faktičnost transcendentální roviny, pak fenomenologie naráží na hranici svého původního východiska, na hranici vědomí, jež musí být chtě nechtě překročena. Proto se Barbaras dále uchyluje k systémovým (gestaltovým) biologům (Goldstein, Straus, von

${ }^{27}$ Jedná se o Barbarasův - podle mého ne př́liš št’astný - termín, jímž se snaží pokrýt ony Husserlovy „vágní", nekonečné „možnosti uskutečnitelného prožívání a konání“. Vybírá ho patrně proto, aby touhu života kontrastoval s jednotlivými potřebami živého tvora a odlišil tak jedno od druhého. Touha je transcendentální rovinou historie kosmu (o které záhy ukážeme, že je ve svém původu empirická), v níž se (nejen) lidské vědomí teprve může ustavit. Tato rovina je utvářena interakcemi mezi živými bytostmi a jejich prostředím. Historie kosmu je historií utváření a neustálé rekonstituce „transcendentální" roviny. 
Weizsäcker), aniž by opustil významné fenomenologické analýzy (Patočka ${ }^{28}$, Merleau-Ponty, Ricoeur) a identifikuje touhu jako komplexitu života, v němž organismus a prostředí splývají a vytvářejí dějinný horizont vlastní faktičnosti (srov. Barbaras, 2005, s. 153-168). Jinými slovy z pohledu fylogeneze je transcendentální rovina sedimentací pravidelností na rovině empirických událostí určitého druhu (např. homo sapiens sapiens). Ovšem tento druh má nepřetržitou návaznost na druhy ostatní - člověk na primáty, na další savce, na další obratlovce atp. Významový horizont člověka tak nekončí v člověku a jeho společnostech, ale utváří se v dějinném pohybu všeho živého. Společně s Ricoeurem Barbaras tvrdí, že aniž bychom vystupovali $\mathrm{z}$ fenomenologické tradice, dostáváme se ke kosmologii, $\mathrm{v}$ níž se objevuje rámec určité ontologie, která je společná pro oblast př́rody i pro oblast vědomí (Barbaras, 2005, s. 174).

A přesně to jsem měl a mám na mysli, když ve svých textech píšu (srov. např. in Gulová \& Šíp, 2013, s. 22-37), že nové paradigma rozpouští radikální odlišení přírodních a sociálních (humanitních) věd na rovině onto-gnozeologické. A tím také rozpouští mimo jiné i radikální odlišení kvantitativních a kvalitativních metodologií. Z těchto radikálních opozic zůstane kontinuita disciplinovaného vědeckého výzkumu bez apriorních hranic. Kontinuita povede od věd, jejichž region vědeckého zkoumání lze idealizovat relativně snadno až $\mathrm{k}$ těm, které se idealizaci díky charakteru svého předmětu významně brání. Ve fyzice, chemii lze snadno použít postupy kvantitativních metodologií, protože jejich fenomény lze snadno idealizovat a redukovat jen na některé vlastnosti. ${ }^{29}$ Kontinuita však pokračuje dál k vědám o životě, kde idealizace naráží na problém zpětných vazeb reflektivity živé tkáně a vědomí, jež jsou produkty tělesnosti. Tyto zpětné vazby, jejich vázanost na hodnoty, jejich nárůst a seberekonstituce omezují možnost masivního použití

28 Barbaras několikrát upozorňuje na hlubokou souvislost své touhy s Patočkovým pohybem (srov. Barbaras, 2005, s. 170, 175).

29 Když však tyto idealizace zpětně reflektujeme, zjištujeme, že naše teorie - např. o subatomárních dějích - nejsou reálným zachycením toho, co existuje (nejsou „náležitým obrázkem“), ale spíše praktickými postupy, jak lépe tyto děje ovládat a předvídat (srov. např. Gribbin, 1998). Na druhou stranu jsou přesně tím, čím je a má být věda v pozdně moderním paradigmatu. To, že nemůžeme kvantitativní metodologii využít v sociálních vědách natolik jako ve fyzice a chemii, je důsledkem skutečnosti, že takto vzniklé teorie nám mnohem komplexnější a reflektivnější realitu předmětů sociálních věd nepomáhají ovládat a předvídat, ale naopak nás matou a svádí z cesty. 
kvantitativních přístupů. ${ }^{30}$ A nakonec kontinuita končí u těch věd, které musí počítat s největší koncentrací zmíněných zpětných vazeb v lidských jedincích a jejich společenstvích (psychologie, sociologie, pedagogika). Zde využití převážně kvantitativních metod vede ke ztrátě vlastního předmětu, protože $\mathrm{v}$ nepřiměřené idealizaci tohoto předmětu se ztrácejí pro něho charakteristické hodnoty a normy, jež jsou inherentní součástí vysoké koncentrace „tkáně reflektivity“. Jedná se ale stále o kontinuitu. Jednotlivé oblasti pokrývané zmíněnými vědeckými disciplínami se proto od sebe nedají striktně odlišit a vysoká koncentrace „tkáně reflexivity“ ve vědách o člověku neznamená, že za určitých a předem dobře promyšlených okolností se v této oblasti nemohou použít kvantitativní metody.

Tato kontinuita disciplinovaného vědeckého výzkumu je prvním ze závazků, které vyplývají z fenomenologické analýzy povahy transcendentální roviny. Druhým závazkem, který z toho pro vědu obecně - a pedagogiku zvlášt' vyplývá, je obrat $\mathrm{k}$ tělesnosti. Právě v tělesnosti ${ }^{31}$ se tato transcendentální rovina utváří do podoby dynamické struktury významů. V ní jsou zakódovány hodnoty a normy, které utvářejí smysluplnou jednotu života. Smysluplná struktura života, která tvoří svoji dynamickou jednotu, nám umožňuje analyzovat situaci, vést ji k její určité podobě - determinovat ji (viz předešlou část) - a př́padně ji řešit. Pokud máme stanovit cíl ve výhledu, neobejdeme se bez zkoumání hodnot, které jsou přítomné v dané situaci.

Například zdraví je hodnota, která vede naše zkoumání a následné jednání. Zde však nesmíme udělat chybu v pojetí řádu této hodnoty - nesmíme ztotožňovat hodnotu s hodnocením této hodnoty. Stejná hodnota (zdraví/ nemoc) může být interpretována odlišně. Pokud mě někdo chce zabít, je pro něho moje onemocnění dobrem a bude hledat takové kauzální řetězce jednání, jejichž uplatnění povedou k mé nemoci a př́ípadné smrti. Pro mě je onemocnění zlem, a proto budu sledovat zcela jiné řetězce - takové, které povedou k zachování zdraví nebo k mému uzdravení. Hodnocení je tedy různé, ale hodnota zakódovaná do prŕírody samotné, do mého naturálního a sociálního

30 K tomu viz předešlá poznámka. Dále to je také důvod, proč se soudobá biologie, aniž by zanevřela na kvantitativní metody, obrací k fenomenologii a k fenomenologickým postupům budování teorie - $\mathrm{k}$ tomu viz Thompson (2007).

31 Vědomě se zde vyhýbám pojmu tělo. Na základě analýz dalších fenomenologů (především Merleau-Pontyho, Ricoeura, Levinase i samotného Barbarase), na jejichž představení zde není prostor, bychom měli tělesnost chápat jako funkci, v níž se transcendentální/faktická rovina utvárí a sedimentuje do tělesné konstituce jednotlivých tvorů jako jednotlivců, jako celého druhu i jako života obecně. 
života v př́rodě, je stejná pro všechny. Rozpor mezi hodnocením jednotlivých aktérů je pak velmi těžkým úkolem etiky, ale i ta je vkořeněna do systému hodnot daných dynamickou strukturou smyslu života. ${ }^{32}$

$\mathrm{Z}$ tohoto důvodu musíme $\mathrm{v}$ pedagogice daleko více věnovat pozornost tělu a tělesnosti. Nikoli jako mechanickému nosiči pedagogického výkonu či cíli pedagogického působení, ale jako zdroji nedocenitelných informací, které současný pedagogický výzkum z velké části postrádá či nereflektuje, protože pro ně nemá dostatečné filozofické a metodologické nástroje. Nemá je, nebot' vychází převážně z raně moderního, neopozitivistického předporozumění. Proto je např́iklad výzkum tacitních znalostí mimo obzor současné pedagogické vědy. Tacitní znalost $v$ tomto paradigmatu je totiž uchopitelná bud' jako ještě nepř́tomný prvek, anebo jako velice rozporuplná parodie na skutečný poznatek. $V$ tomto paradigmatu je znalost bud' explicitní, anebo není vůbec. Samozřejmě že víme $\mathrm{z}$ každodenní zkušenosti, že jsme schopni dělat věci, pro které nám chybí explicitní vyjádření. Proto také vznikají desítky a desítky výzkumů, ty se však se skutečnou podstatou tacitní znalosti většinou míjí. Nepracují se znalostí jako dynamickou kontinuitou mezi jejími explicitními a implicitními aspekty, jejichž části se podle kontextu a situace přesouvají z explicitní do implicitní fáze a naopak.

Stejně tak jsou ve výzkumu velice málo využity dramatické techniky. Ty jsou v pedagogice nanejvýše brány jako didaktický, popřípadě intervenční prostředek. Pokud však vážně vezmeme roli tělesnosti pro utváření dynamické struktury významu, pak mnoho informací můžeme získat díky aplikaci dramatických simulací tělesného jednání. ${ }^{33}$

\section{$5 \quad$ Metodologické důsledky}

Tato rekonstituce filozofických východisek moderny vede k utváření tří navzájem se překrývajících kontinuit. Kontinuita „realit“" ${ }^{34}$ dříve od sebe striktně oddělených regionů (fyzická realita, biologická realita, psycho-sociální realita) je zkoumána kontinuitou (dř́ve př́liš striktně oddělených) vědeckých disciplín. A tato druhá kontinuita využívá kontinuitu metodologických nástrojů. Jaké metodologické nástroje výzkumníci využijí, již dále nebude

32 K tomu srov. Deweyho u nás téměř neznámou knihu Theory of Valuation (Teorie hodnocení) (lw.13. 189-251).

33 K tomu více viz Šíp (2013).

34 Žádám čtenáře, aby toto slovo brali jako pracovní, ne př́iliš štastný výraz, ke kterému jsem se uchýlil, protože jsem nenašel lepší. 
předem definováno tím, zda se údajně nacházíme v tzv. „přírodních“ nebo tzv. „sociálních“ vědách, ani skutečností, že v určitém časovém horizontu $\mathrm{v}$ nějaké $\mathrm{z}$ „realit“ převládal jeden typ metodologie (např. „kvalitativní“ nebo např. „kvantitativní") a je údajně nutné „vychýlit kyvadlo“ k druhému pólu (srov. Jirásek, 2015, s. 489).

Mnohé ze současných pedagogických výzkumů nejsou a priori špatné proto, že by využily kvantitativní metodologii, ale zkrátka proto, že využitím této metodologie dostaly takové výsledky, které jsou nesmyslné nebo zcela zbytečné - v obou případech v praxi nepoužitelné. Jestliže chceme proměnit klima třídy (to je praktická hodnota, která vytváŕí cíl ve výhledu a startuje kognitivní akt - k tomu viz část třetí) a danou „realitu“ klimatu idealizujeme pouze na ty prvky ovlivňující klima, které lze 1) snadno od sebe odlišit a 2) snadno operacionalizovat, pak si hned v prvním kroku výzkumu vytváříme svůj vlastní idealizovaný svět, svět zcela odlišný od reality, ve které žijeme a kterou jsme se rozhodli zkoumat. ${ }^{35}$ Podstatou idealizace je redukce bohatosti fenoménu na předem vybrané vlastnosti a charakteristiky. V některých „realitách“ takové redukce vedou ke ztrátě předmětu, který má být zkoumán. Většinou však přesně takové výzkumy lze prosadit do časopisů s vysokým impakt faktorem.

Ovšem neměli bychom zde vytloukat klín klínem a pouze střídat jednu nefunkční jednostrannost druhou. Důvodem je skutečnost, že mnohé ze současných kvalitativních pedagogických výzkumů nejsou a priori špatné proto, že použily podezřelou, tzn. „měkkou“, kvalitativní analýzu, ale prostě proto, že nedodržují náležitý postup vybrané metody, a proto nezjišt'ují takové informace, jaké zjistit chtěly. Jestliže např. ve fenomenologické metodě neuskutečníme fázi epoché a fenomenologické redukce, pak jsme schopni produkovat analýzu blízkou postupu otevřeného kódování, ale v každém případě jsme se tímto způsobem nemohli dostat k horizontalizaci a fenomenologické struktuře smyslu, které jsou cílem využití fenomenologie ve výzkumu. ${ }^{36}$

35 K tomu navíc srov. moji analýzu procesů hermeneutického kruhu během faktorové analýzy klimatu třídy (in Gulová \& Šíp, 2013, s. 25-27), která slouží jako pars pro toto k celé problematice využití kvantitativních postupů v pedagogice.

$36 \mathrm{~V}$ této souvislosti je dobré připomenout, jak se $\mathrm{s}$ epoché a $\mathrm{s}$ fenomenologickou redukcí vyrovnala MCA (analýza konstituce významů - meaning constitution analysis) Rogera Sagese, a zároveň je dobré zmínit Sagesovy pochybnosti, které opakovaně vyjádřil na svých brněnských seminářích o MCA (v letech 2010 a 2014), pochybnosti, zda IPA (interpretative phenomenological analysis) tak, jak ji předkládá Smith a jeho kolegové (viz např. Smith, Flowers, \& Larkin, 2009), je skutečně fenomenologickou metodou. 
Ovšem zde jsme stále na začátku. Pro náležité uchopení tohoto problému musíme pochopit centrální část nového paradigmatu. Podstatou paradigmatického obratu je fakt, že pozitivistická, stejně jako fenomenologická a hermeneutická východiska vznikala ještě v rámci starého raně moderního paradigmatu a chtě nechtě se pod tlakem vlastních rozporů navzájem rekonstruují. Vezměme si př́klad z Husserlovy kritiky pozitivismu a psychologismu v Krizi věd (Husserl, 1996) a Deweyho kritiky objektivistického realismu a pozitivismu v The Logic of Judgments of Practice (srov. Dewey, 1992, mw.8: 14-82). ${ }^{37}$ Obě mají společné to, jakým způsobem kritizují konstrukci pojmu „objektivní" poznatek. Obě ukazují, že co je objektivistickým realismem a pozitivismem (psychologismem) považováno za vstupní data - jednotky percepce a reprezentace (sensation, idea), jsou ve skutečnosti již analytickými jednotkami, které byly idealizací utvořeny z původního proudu zkušenosti. Husserlova kritika ukazuje, jak je tato původní zkušenost vnitřně konstituována transcendentální rovinou a že je to tedy tato rovina, která předchází a umožňuje nejen „objektivní" poznatek, ale jakékoli smysluplné prožívání. Barbarasova kritika Husserla (velmi podobná Deweyho důrazu na metanarativ evolucionismu aplikovaný na filozofická východiska pragmatismu) ukazuje, jak se transcendentální rovina empiricky ustanovovala jako fylogenetické a posteriori, které se z ontogenetického hlediska jeví jako apriorní, tzn. předem dané před vší empirickou zkušeností. ${ }^{38}$

Tento zvrat transcendentality ve fakticitu vytváří zcela nové pojetí vědeckého poznatku (záměrně se zde vyhýbám sousloví „objektivní poznatek“). Jestliže tato fakticita/transcendentalita ovlivňuje naše prožíání způsobem, že ji strukturuje do smysluplné zkušenosti, a jestliže zároveň je tato fakticita/transcendentalita zapsána v nejvnitřnějších částech všech jednotlivých „já" daného druhu, pak se rozpouští původní radikální odlišnosti mezi „tvrdými“ a „měkkými“ fakty, mezi reliabilitou poznatků získaných kvantitativními a kvalitativními metodami, mezi vnitřkem (subjektivitou) a vnějškem

37 Text byl mimochodem uveřejněn již v roce 1915, tedy v době, kdy Husserl začínal promýšlet intencionalitu způsobem, jenž vedl k překonání raně moderního odkazu ve fenomenologické tradici.

38 Termín fylogenetické a posteriori si vypůjčuji od Konrada Lorenze, který byl přesvědčen ještě před vznikem fenomenologie merleau-pontyovského typu, že kantovská transcendentální rovina je ve skutečnosti sedimentací důsledků empirických událostí, které probíhaly během fylogenetického vývoje a zapisovaly se do genetické výbavy daného druhu (srov. Lorenz, 1982 - první vydání 1941). Právě tuto skutečnost měl Barbaras na mysli, když se od transcendentálního stanoviska husserlovského projektu obrátil k Ricoeurově kosmologii. Kosmologii, v níž existuje společný základ pro př́írodní i společenské vědy. 
(objektivitou). K některým druhům poznatků - $\mathrm{k}$ těm, které se váží na předzjednanou smysluplnost prožívání, a tedy mimo jiné na hodnoty a normy - se nedostáváme idealizací předmětu a zjištěním pravděpodobnosti jejich vzájemných vztahů a výskytů (což je podstata kvantitativní metodologie), ale naopak se $\mathrm{k}$ nim dostáváme návratem $\mathrm{k}$ faktičnosti transcendentální roviny. ${ }^{39}$ V tomto kontextu dostává zcela nové aktuality - zpočátku těžko pochopitelné - Sagesovo tvrzení, že při dobře provedené fenomenologické analýze se $\mathrm{v}$ pedagogice a psychologii dostáváme $\mathrm{k}$ „objektivnějším“ (lépe vyjádřeno: relevantnějším) informacím, než jaké mohou poskytnout kvantitativní metody, a to i za té podmínky, že výzkumný vzorek může být relativně malý. ${ }^{40}$ Ony informace jsou „vědecky důvěryhodnější“ či relevantnější (těmito pojmy se snažím vyhnout raně modernímu termínu „objektivnější"), protože idealizací, na níž jsou postaveny kvantitativní metodologie, odfiltrováváme struktury smyslu prožívání, a tedy redukujeme předmět našeho zkoumání způsobem, jenž je často devastující pro kvalitu poznatku a jeho využití v reálné situaci.

Tím neříkám, že jsou kvantitativní postupy zbytečné nebo falešné. Upozorňuji tím pouze na skutečnost, že se s těmito východisky dostáváme za horizont raně moderní vědy. Kvantitativní metody nezjišt’ují „tvrdá" fakta - tedy taková, která nám ř́ḱkají „jak se to se světem skutečná má“, fakta, jimiž údajně vládnou pouze či především přírodní vědy. Je tomu tak proto, že předmět svého výzkumu hned na vstupu idealizují, a tím významně manipulují jak ona vznikající fakta, tak i jejich využití v technologiích. Charakteristikou těchto metod není větší objektivita, ale větší potenciál technologické manipulace. Tento potenciál je větší, protože jsou fakta již na vstupu idealizována, nexus sítové kauzality dynamických systémů je proměněn na relativně jednoduché lineární řetězce prŕícin a následků. Manipulovatelnost takových „faktů“ je mnohonásobně jednodušší. Právě na této technologické manipulovatelnosti spočíval úspěch raně moderní vědy.

39 Tento „návrat“ raně moderní paradigma neštastně chápalo jako „ponor do hlubin subjektu“, ztotožnilo takové poznatky se „subjektivností“ a děsilo se „subjektivizace poznání“. Tím zmíněné paradigma tyto poznatky diskvalifikovalo předem, nebot' „subjektivní" poznatky následně musely být z principu raně moderní ideologie poznání objektivizovány. Objektivizovány nejčastěji byly prostřednictvím kvantitativní metodologie. Avšak idealizace, která je podstatou kvantitativních přístupů, z velké části vymazala to, co tvoří strukturu smyslu vysoce reflektivních a na kontext vázaných informací.

40 Sages toto opakovaně prohlásil na svých seminářích o MCA, které byly organizovány Katedrou sociální pedagogiky PdF MU v letech 2010 a 2014. 
Kvalitativní metody zase neposkytují „měkká“ data, nebot’ se dostávají ke strukturám smyslu, jež mají velice „tvrdé“ pozadí, protože mimo jiné zajištujú přežití daného biologického druhu. Silně strukturovaná edukace je pro přežití druhu homo sapiens sapiens nezbytností, ale právě pedagogická činnost je vysoce závislá na hodnotách situací, v nichž je prováděna. Je vázána kontextem a situovaností mnohem více, než činnost na poli fyziky nebo chemie. Př́liš velký sklon k idealizaci v pedagogickém výzkumu boří zevnitř tuto situovanost a hodnotovost a činí získaný „poznatek“ v praxi fakticky nepoužitelným. "Měkké" fakty jsou sice nesmírně důležité, ale podstatně hưře se s nimi manipuluje. $Z$ principu věci kvalitativní metodologie omezuje idealizaci vstupních jednotek a zachovává strukturní složitost fenoménů. Přesto jsou poznatky získané prostřednictvím kvalitativní metodologie v komplexních problémech často rozhodující.

Ze všech těchto důvodů jsou dnes pojmy jako „objektivní" a „subjektivní“, „tvrdá“ a „měkká“ (data) málo relevantní a spíše nás matou, než že by nám pomáhaly. Hlavními otázkami, které rozhodují o použití metodologických nástrojů, proto jsou nikoli ty, které se ptají, zda se jedná o př́rodní nebo sociální vědy, ale otázky následující: Jaký je charakter našeho předmětu? Z jaké kontinuity „realit“ pochází? Lze tuto „realitu“ snadno idealizovat? Co se idealizací ztratí? Je takový idealizovaný poznatek využitelný v praxi, anebo jen rozšiřujeme formalismus nepotřebných „poznatkü“ a „teorií"? Jaké alternativy výzkumných nástrojů mi zbývají? Přesně tyto otázky jsou podstatou toho, co má podle mého na mysli profesor Čermák, když mluví o „pozadí skutečně disciplinovaného vědeckého výzkumu“. ${ }^{41}$

\section{Důsledky pro pedagogické teorie}

Tato meta-vědecká analýza na úrovni teorie a filozofie vědy má hluboké dopady také na rovinu teoretickou. To se na konkrétnější úrovni teorií projevuje mimo jiné skutečností, že pokud pedagogika nebude dostatečně reflektovat filozoficko-teoretické pozadí pozdně moderních teorií, nebude ze systémových důvodů schopna je plně akceptovat. Díky tomu nikdy zcela nedocení dílo nejvýznamnějších vědců, kteří se již v pedagogice stali ikonami - Dewey, Piaget či Vygotský a jejich následovníci. Vezměme si na př́́klad Piageta.

41 Ivo Čermák „pozadí skutečně disciplinovaného vědeckého výzkumu“ zmínil během semináře o interpretativní fenomenologické a narativní analýze, který v červnu 2015 organizovala Katedra sociální pedagogiky PdF MU. 
Přestože mnohé pedagogické teorie vycházejí z poznatků Piagetova zkoumání, velká většina z nich fakticky nepracuje s východisky jeho teorií. Nepracuje např. s kontinuitou senzomotorických reakcí, instinktivního jednání, zvyků na jedné straně a vyšších kognitivních procesů na straně druhé. Nepracuje s kontinuitou emocí na jedné a inteligencí na druhé straně. Všechny zmíněné kontinuity vyplývají z homeostatické teorie vztahu člověka a jeho prostředí, o níž jsem psal ve 3. části.

Neznám žádnou z pedagogických teorií, která by vědomě a důsledně pracovala s Piagetovou intencí jeho teorie akomodace a asimilace. Tato teorie je významná, protože ukazuje kognitivní aktivitu jako produkt vzájemné interakce mezi poznávajícím a poznávaným, přesněji zdůrazňuje jejich výchozí jednotu, která se teprve v reflexi rozpadá na zmíněné póly. Akomodace a asimilace jsou prostředky, jakými se dosahuje homeostatického stavu, díky kterému organismus vedle dalších benefitů nabývá znalostí a dovedností (Piaget, 1999, s. 20-21). Homeostatický stav je naprosto stěžejní pro další Piagetovy myšlenky, protože ruší raně moderní odlišení subjektu a objektů, se kterými subjekt nakládá. Propojuje dítě s jeho okolím, a tak zvýrazňuje externí podmínky rozvoje jeho inteligence. Dává smysl jak genetickému potenciálu pro formování lidské inteligence, tak zároveň zviditelňuje další faktory nutné $\mathrm{k}$ jejímu plynulému rozvoji mimo tělo dítěte $\mathrm{v}$ jeho sociálním a environmentálním prostředí (srov. Piaget, 1999).

Stejně tak se daří Vygotskému či Deweymu. Přestože jejich jména najdeme téměř v každé pedagogické publikaci, jejich myšlenky jsou přebírány (opisovány) většinou pouze nominálně, nikoli reálně. Není v tom zlý úmysl ani lenost. Reálné teorie těchto pedagogů/psychologů/filozofů zcela překračují horizont raně moderního myšlení, a proto jsou podvědomě odsouvány na okraj, směšovány s pro ně cizími východisky, popř. proměňovány zcela $\mathrm{v}$ teorie slučitelné s raně moderním vnímáním. Tím je ale původní záměr jejich autorů zevnitř destruován. ${ }^{42}$

Podíváme-li se do současné literatury, kterou kvalitně shrnuje autorský kolektiv kolem Tomáše Janíka, dostáváme velice plastický obrázek, jak je na tom současná pedagogická teorie. Nachází se v matoucím procesu přechodu,

42 Ve svém nedávno dokončeném textu jsem tento pohyb dokumentoval na historii českého přijetí Deweyho pedagogiky, díky kterému je Dewey zcela proti logice jeho pedagogické filozofie pojímán jako představitel tzv. „pedocentrického přístupu“. Málokterá nálepka může být od skutečného Deweyho záměru tak vzdálená (srov. Šíp, 2015). 
v němž se ve výzkumech a teoriích mísí prvky rané moderny s intuicemi moderny pozdní. Např́íklad v části, kde se tematizuje i Piaget (srov. Janík, Maňák, \& Knecht, 2009, s. 121-138), se nacházejí vedle sebe představy a koncepty, které jsou navzájem neslučitelné. Na jedné straně zapadají do klasického pojetí - např. Fodorova teorie znalosti jako něčeho, co je procesováno v mysli separované od materiálního, kulturního a sociálního prostředí (srov. Janík et al., 2009, s. 125). Na druhou stranu je zde představována teorie „učení jako stávání se členem komunity“ (Janík et al., 2009, s. 126).

Jiným př́kladem podobné mesaliance je pojetí konceptu a prekonceptu. Jednou je s nimi nakládáno jako se striktní opozicí, podruhé jako s kontinuitou, jejíž konkrétní hodnota je relativní k dané situaci. Ve chvíli, kdy se zdůrazňuje skutečnost, že expert ví o dané realitě víc než žák nikoli proto, že se tématem zabývá dlouhodobě z mnoha úhlů pohledu a vybírá jeden privilegovaný pohled - ten, který je v současnosti považován za nejvíce vědecký, nýbrž proto, že uchopil pravou podstatu poznatku o dané skutečnosti, je s touto dvojicí pojmů zacházeno jako se striktní opozicí. Tím se ale zakrývá skutečnost, že samotný vědecký koncept je nějakým způsobem motivovaný a že jsou informace o dané realitě předem speciálně filtrované a tříděné a že takové poznatky mají instrumentální charakter (viz výše pasáže o instrumentální podstatě pozdně moderní vědy). Na druhou stranu je uznáno, že „veškeré poznání má jednotné věcné a empirické východisko pro experta i žáka, nebot' oba jsou vystaveni nezbytnosti vycházet ze své dosavadní zkušenosti“, čímž se připouští ona kontinuita, v níž může být pracováno s dosavadními znalostmi velmi pružně - tak, jak si to vyžaduje konstruktivistický přístup ve výuce (srov. Janík et al., 2009, s. 127-130).

Podobný proces lavírování mezi raně moderním a pozdně moderním paradigmatem je příčinou toho, proč je Hejného metoda ${ }^{43}$ mediálně populární, ale fakticky nepochopená. Vzbuzuje velké naděje a vášně, které lze snadno přetavit do mediálně vděčných, jednoduchých př́iběhů, ale málokdo skutečně chápe, na jakých principech je založena. U rodičů a neziskových organizací se jí dostává nekritické podpory, ale vysokoškolští odborníci na pedagogiku

43 Mnohé informace o Metodě, nejen teoretického a teoreticko-didaktického charakteru, lze nalézt na stránkách www.h-mat.cz. Archív Víta Hejného - zakladatele metody - vydal první díl jeho sebraných spisů. Je překvapivé, jaká důvěrná blízkost existuje mezi touto metodou a teoriemi Piageta, Vygotského, Deweyho a dalších (srov. Hejný, 2012). Je to o to více překvapivé, že Vít Hejný neměl k odborné literatuře $\mathrm{z}$ „imperialistického tábora“ téměř žádný př́stup. 
jsou k této metodě - kulantně řečeno - opatrní. Důvodem obou typů reakcí je neznalost skutečných východisek. Málokdo vidí za Hejného metodou teorii, která počítá s fylogenetickou souvislostí mezi vývojem lidského mozku a mezi ontogenetickými procesy učení. Podobně jako v Deweyho výuce prostřednictvím reálné smysluplné aktivity (occupational education) viděli jeho kritici pouze nezávaznou hru (srov. Šíp, 2015), vidí mnozí pozorovatelé Hejného způsobu výuky např v „krokování“ - tj. v jednom z matematických „prostředí", kterými Hejného metoda dítě provází - pouze motivační prvek. Málokdo si uvědomuje, že transcendentalita matematických vztahů (tím se vracím k Barbarasově kritice Husserla a k významnosti této kritiky pro pedagogiku) se empiricky utvářela během vývoje člověka jako druhu. To umožňuje geneticky zakódovat podmínky pro matematické myšlení a reprodukovat je v jedinci další generace. Když dítě prochází procesem modulování matematických vztahů, rekonstituuje se z geneticky přenesených podmínek podstatná část matematického prostoru $\mathrm{v}$ jeho „hlavě“. V tomto procesu dítě zpočátku musí a později může zapojovat senzomotorická centra, která se aktivovala v dobách druhové konstrukce této schopnosti.

Jestliže zůstaneme na pozici rané moderny, pak je samozřejmě Hejného metoda pouze bonbónkem na dortu, jakousi radostí, kterou si můžeme, ale nemusíme dopřát - protože zkrátka dítě bud' matematické myšlení má, anebo nemá, bud' mu je tato inertní a od něho odlišná matematická transcendence dostupná, anebo nikoli. $V$ takové logice ti, kteří ho nemají v dostatečné míře, se kupecké počty naučí drilem a skutečná matematika je pro ně jen ztrátou času. Jestliže však bereme vážně paradigmatický obrat, pak se nám celý obraz jeví jinak. Chápeme proměnu pravidelností empirických událostí v transcendentální rovinu smyslu, kterou jako jednotlivci využíváme, když vedeme své životy. Máme pak také daleko pestřejší paletu pro didaktickou transformaci obsahu výuky i pro výukové metody a pro konstrukci výukových prostředků.

Způsoby transformace a z nich vyplývající metody a prostředky nejsou nahodilé. Proto oběma profesorům Hejným tato fáze zabrala celé jejich životy. Jsou postaveny na hluboké znalosti lidského jednání, na stovkách a stovkách pozorování, stovkách výzkumů a desítkách a desítkách reformulací základních myšlenek do detailního popisu psychologie a sociologie učení (srov. Hejný, 2012, např. 213-293). Takový teoretický vhled umožňuje pochopit zcela odlišným způsobem výuku matematiky. At' už vědomě, či podvědomě, je tento vhled postaven na změně paradigmatického vidění. 
Hejného metoda pracuje především s jednáním učitele, nebot' vidí hlubokou kontinuitu mezi žákem a učitelem a může modulovat dění „uvnitř hlavy“ žáka prostřednictvím zdánlivě vnějšího jednání vyučujícího. Na stránkách H-matu, i na letních školách Hejného metody se dozvíte, že největším oříškem pro náležitou aplikaci Metody je kompletní proměna chování a uvažování učitele. Milan Hejný to často formuluje bonmotem, že „zatímco tato metoda je pro každé dítě, není pro každého učitele“. Z pohledu pozdně moderního pojetí edukace je to pochopitelné. Hluboká změna v chování a myšlení učitele zákonitě vede $\mathrm{k}$ hlubokým proměnám stylů učení žáka, protože žák a učitel tvoří kontinuum pedagogického procesu. Na konkrétním prríkladu se nám zde znázorňuje podstata paradigmatického obratu. Původní je relace, vztah. „Subjekt“ a „objekt" výuky jsou až následné idealizace pedagogického procesu. Žák může být „subjektem“ výuky nebo „objektem“ podle toho, jakou strategii vyučující zaujme. Paleta výukových strategií je dána ontologickou původností vztahu.

Profesor Hejný také ví či podvědomě „ví, že stádia uchopování matematického prostoru jsou pročištována a urychlována tím, že se idealizace matematických vztahů zpětně somatizují v činnosti dětí. Tato somatizace je hlavním principem didaktické transformace obsahu výuky. Děti krokují, baví je to, ale nejde primárně o motivaci. Jde-li zde o něco, pak o radost z poznání, která přichází během celého procesu „krokování“. Jde o poznání. Hrou se tento styl výuky stává proto, že dítě je ke znalosti abstraktních prostorů matematiky přiváděno prostřednictvím naprosto samozřejmých pohybů jeho těla (popř́padě naprosto samozřejmých způsobů jednání, v němž somatická dimenze hraje roli bezproblémové lehkosti, klidu a bezpečí). Tato samozřejmost a přirozenost kopíruje faktické utváření matematických vztahů, kopíruje jejich sedimentaci v jednání člověka jako druhu a jejich využívání v běžném životě. Tedy kopíruje procesy, které proběhly ve fylogenetickém vývoji člověka. Všechny tyto předpoklady jsou v souladu s nejnovějšími poznatky evoluční biologie, evoluční lingvistiky a kognitivních věd druhé generace ${ }^{44}$ (srov. např. Lakoff \& Núnez, 2000).

Samozřejmě i Hejného metoda často trpí skutečností, že se jedinečnosti a komplexnosti této metody chápou média, př́liš naivní aktivisté a znechucení učitelé. Ve všech třech skupinách jsou tací, kteří ji prodávají za drobné. Média vytvářejí zbytečnou rivalitu mezi proponenty jednotlivých metod.

\footnotetext{
44 K odlišení první a druhé generace kognitivních věd viz Lakoff a Johnson (1999, s. 71-74).
} 
Rodiče primárně chtějí, aby matematika děti „bavila“, ale nesledují hlavní cíl poznání. Mnozí učitelé si vytrhávají některé postupy z celku Metody a zbavují ji tak hlubokého vědeckého kontextu. Všechny tyto reakce jsou projevem nezamýšlených důsledků starého paradigmatu, které souvisejí s celkovou rolí pedagogiky v době rané moderny. (Ale to je téma na samostatnou stat'.)

\section{Shrnutí}

V této studii jsme sledovali komplexní změnu v pojetí vědy, která dnes probíhá. Poznání je v tomto pojetí chápáno jako instrumentální jednání vedoucí $\mathrm{k}$ cíli. Tento cíl je ale dán hodnotami uloženými v transcendentálním horizontu našeho života. Transcendentalita má svůj fylogenetický původ, je svým původem empirická. Zvratnost transcendentality $\mathrm{v}$ empirickou fakticitu umožňuje pochopit poznání zcela novým způsobem. A tento nový způsob se promítá i do reformulace pojetí pedagogiky. Nové pojetí poznání redefinuje vztah kvantitativní a kvalitativní metodologie. Zvláště v pedagogice má tento posun závažné důsledky. K velkému posunu dochází i v utváření a využívání teorií. Díky těmto posunům na rovině teorie je náhle mnohem srozumitelnější např. podstata Hejného metody. Všechny tyto změny výrazně proměňují horizont sebeporozumění jednotlivých vědeckých disciplín. Zvlášt' významné posuny můžeme očekávat $\mathrm{v}$ pedagogice.

\section{Literatura}

Barbaras, R. (2005). Touha a odstup. Praha: Oikoymenh.

Brezinka, W. (2001). Východiska k poznání výchovy. Brno: L. Marek.

Davidson, D. (2004). Mýtus subjektivního. In D. Davidson, Subjektivita, intersubjektivita, objektivita (s. 55-71). Praha: Filosofia.

Dewey, J. (1992). The collected works of John Dewey. L. A. Hickman (Ed.). Charlottesville: InteLex Corporation.

Foucault, M. (2000). Slová a veci. Bratislava: Kalligram.

Foucault, M. (2002). Archeologie vědění. Praha: Hermann \& synové.

Gadamer, H.-G. (2010). Pravda a metoda I. Praha: Triáda.

Gribbin, J. (1998). Pátrání po Schrödingerově kočce. Kvantová fyzika a skutečnost. Praha: Columbus.

Gulová, L., \& Šíp, R. (2013). Výzkumné metody v pedagogické praxi. Praha: Grada.

Hejný, V. (2012). Archív Víta Hejného I. H. Bachratý (Ed.). Žilina: EDIS-vydavatel'stvo Žilinskej univerzity.

Henry, M. (2010). Neintencionální fenomenologie: úkol pro příští fenomenologii. Materiální a hyletická fenomenologie. In K. Novotný (Ed.), Co je fenomén? Husserl a fenomenologie ve Francii (s. 111-166). Praha: Filosofia. 
Husserl, E. (1996). Krize evropských věd a transcendentální fenomenologie. Praha: Academia.

Husserl, E. (2007). Formální a transcendentální logika. Praha: Filosofia.

Janík, T., Maňák, J., \& Knecht, P. (2009). Cíle a obsahy školního vzdělávání a metodologie jejich utváření. Brno: Paido.

Jirásek, I. (2015). Gulová, L., \& Šíp, R. (2013). Výzkumné metody v pedagogické praxi. (Recenze). Pedagogická orientace, 25(3), 487-491.

Kohák, E. (1984). The embers and the stars. A philosophical inquiry into the moral sense of nature. Chicago: The University of Chicago Press.

Kot’a, J. (2015). Václav Př́íhoda, Stanislav Vrána a údajný pragmatismus v pokusné měštanské škole ve Zlíně. In M. Pánková, D. Kasperová, \& T. Kasper (Eds.), Meziválečná školská reforma $v$ Československu (s. 81-97). Praha: Academia a Národní pedagogické muzeum Jana Amose Komenského.

Koubová, A. (2011). Myslet ze št’astného těla. Filosofický časopis, 59(1), s. 91-112.

Kuhn, T. S. (1997). Struktura vědeckých revolucí. Praha: Oikoymenh.

Lakoff, G. (2006). Oheň, ženy a nebezpečné věci. Praha: Triáda.

Lakoff, G., \& Johnson, M. (1999). Philosophy in the flesh. The embodied mind and its chalange to western thought. New York: Basic Books.

Lakoff, G., \& Núnez, R. (2000). Where mathematics comes from: How the embodied mind brings mathetmatics into being. New York: Basic Books.

Levinas, E. (1997). Totalita a nekonečno. Praha: Oikoymenh.

Lorenz, K. (1982). Kant's doctrine of the a priori in the light of contemporary biology. In H. Plotkin (Ed.), Learning, development and culture: Essays in evolutionary epistemology (s. 121-143). New York: Wiley and Sons.

Madzia, R. (2014). George Herbert Mead: Tělo, mysl, svět. Praha: Triton.

Menary, R. (Ed.). (2010). The extended mind. Cambridge: The MIT Press.

Merleau-Ponty, M. (2004). Viditelné a neviditelné. Praha: Oikoymenh.

Ochrana, F. (2009). Metodologie vědy. Úvod do problému. Praha: Karolinum.

Patočka, J. (2003). Úvod do fenomenologické filosofie. Praha: Oikoymenh.

Piaget, J. (1999). Psychologie inteligence. Praha: Portál.

Rockwell, W. T. (2005). Neither brain, nor ghost. A nondualist alternative to the mind-brain identity theory. Cambridge: The MIT Press.

Rorty, R. (2012). Filosofie a zrcadlo prírody. Praha: Academia.

Smith, J. A., Flowers, P., \& Larking, M. (2009). Interpretative phenomenological analysis. Theory, method and research. Thousand Oaks: Sage.

Šíp, R. (2013). Tělesné jednání jako základ poznání a výzkumu: divadelní techniky a kognitivní vědy druhé generace. In L. Remsová \& D. Klapko (Eds.), Výzkumný exkurz do dramatické výchovy (s. 25-60). Brno: Masarykova univerzita.

Šíp, R. (2014). Zkušenost v Deweyho experimentální metafyzice: radikální překročení subjektobjektové epistemologie. Organon F, 20(1), 63-81.

Šíp, R. (2015, v tisku). Dewey a „český Dewey“, pedagogika a ideologie. Pedagogika, 65(4).

Thompson, E. (2007). Mind in life. Biology, phenomenology, and the science of mind. Cambridge: Harvard University Press.

Višňovský, E. (2009). Štúdie o pragmatizme a neopragmatizme. Bratislava: Veda. 
Višňovský, E., Kaščák, O., \& Pupala, B. (2012). Pedagogický dualizmus teoretického a praktického: historické pozadie a súčasné ilúzie. Pedagogická orientace, 22(3), 305-335.

Urban, P. (Ed.). (2011). Fenomenologie tělesnosti. Praha: Filosofický časopis a Filosofia. Weber, M. (2009). Metodologie, sociologie a politika. Praha: Oikoymenh.

\title{
Autor
}

doc. Mgr. Radim Šíp, Ph.D., Masarykova univerzita, Pedagogická fakulta, Katedra sociální pedagogiky, Poříčí 7, 60300 Brno, e-mail: sip@ped.muni.cz

\section{Pedagogy and a paradigm shift in methodology and theory}

\begin{abstract}
The study depicts a paradigm shift that changes significantly early modern foundations of science, especially ideas of objectivist realism and the correspondence theory of truth and inquiry. The author introduces basic ideas of the pragmatist theory of inquiry (Dewey), and conclusions of a late phenomenologist movement (Merleau-Ponty, Barbaras, Ricoeur) that recover factual roots of the transcendental level. Both, pragmatism and phenomenology put emphasis on the role of somatic dimension in the process of inquiry. This helps us alter completely the metaphysical basis of modern science. Main changes that the author presents in the study lie in both, methodology and theory. As for the methodological discourse, the author refers to dissolving the border between sciences and human sciences and the border between quantitative and qualitative research. That leads us to replacing the traditional understanding of inquiry by a so-called "continuity of disciplined scientific research". As for the discourse on theory, the author depicts a new role of theory in inquiry and shows great impact of somatic dimension on the process of inquiry. All of these changes alter foundations of modern science as well as of individual scientific disciplines, pedagogy included.
\end{abstract}

Keywords: science, pedagogy, pragmatism, phenomenology, positivism, qualitative/ quantitative research, hard/soft facts 